\title{
Internal Control and Quality of Financial Reporting in Zakat Management Organization
}

\author{
Elis Mediawati \\ Accounting Department \\ Universitas Pendidikan Indonesia \\ Bandung, Indonesia \\ elis.mediawati@upi.edu
}

\begin{abstract}
Zakat is the third pillar of Islam, it must be fulfilled by a muzaki (the person who is obliged to issue zakat), because the rights of others are in the assets which are owned. Zakat in Islam is the worship contains two dimensions they are hablum minallah or vertical dimension and hablum minannas or horizontal dimension [1]. There is very noticeable difference between the zakat potential and its receipt realization by Zakat Management Organization (ZMO). Allegedly the problem occurs because it is lack of public trust to ZMO. Public trust is closely related to the quality of the financial information which is presented by ZMO. The information will be useful if the information is able to support the community decision-making to entrust their zakat to ZMO as an institution which is considered mandate to receive, utilize and distribute zakat which is entrusted by community [1]. Internal control is necessary to obtain the quality of financial reporting. Financial statements are credible information sources by the financial statements users to determine the performance of management and the company's financial position. To produce quality financial reports it is required financial reporting quality. It should also be supported by internal control over quality financial reporting. This study aims to determine the relation of internal control implementation on the quality of financial reporting. The method which is used in this study is a survey method, it is descriptive and verification, and the data is collected from a sample that has been determined, it is obtained by using a specific data collection tools, the questionnaires. The unit of analysis in this study is the ZMO in Bandung city. The hypothesis testing uses moment product correlation and coefficient of determination $\left(R^{2}\right)$. The result of this research is the relation of internal control implementation with the quality of financial reporting is positive and very strong.
\end{abstract}

Keywords-Internal Control, the Quality of Financial Statement Reporting, Zakat Management Organization

\section{BACKGROUND}

Zakat management organization (ZMO) is a lot in Indonesia. ZMO is tasked to collect, manage and distribute zakat. The purpose of this zakat management includes improving services for the public in giving zakat so that the results and efficiency of zakat are increased.

Zakat is an obligation that must be fulfilled by a muzaki (the person who is obliged to issue zakat), because the rights of others are in the assets which are owned. The right is a right which is owned by eight asnaf on property that is owned by muzaki. Zakat is a worship containing two dimensions of hablum minallah or vertical dimension and hablum minannas or horizontal dimension. If zakat worship is accomplished properly it will improve the quality of faith, cleanse and purify the soul, and develop and deliver a blessing on property which is owned.

Indonesian population is majority Moslem so that the zakat potential in Indonesia is huge. Unfortunately the amount of zakat in Indonesia is not absorbed well by amil zakat institutions that exist. There is very noticeable difference between the zakat potential and its acceptance realization by the agency. The cause of the difference is community prefers giving zakat directly to mustahik. Most of community have the view that by giving zakat directly to mustahik it will bring peacefulness compared to entrust it to an institution. In fact, zakat which is given by community does not reach the right target yet when it is administered directly by each of them. There is a possibility of some muzaki give their zakat to the same mustahik. This is where the role of $\mathrm{ZMO}$ is actually needed through the zakat management institution it is expected that zakat distribution to mustahik occurs evenly.

ZMO is less successful as an institution which has the authority to raise and empower zakat, but it does not mean that Muslims do not pay zakat, but it is because the Zakat fund management is not organized yet. Allegedly the problem occurs because it is lack of public trust to ZMO.

Public trust is closely associated with the financial information quality which is presented by ZMO. The information will be useful if the information is able to support the community decision-making to entrust their zakat to ZMO as an institution that is considered a mandate to receive, utilize and distribute zakat which is entrusted by community [1].

Internal control is necessary to obtain the quality of financial reporting. The importance of internal control and the need for effective internal control can help to ensure the company's operational and financial objectives are met forever [2][3]. The effective internal control process must be comprehensive and involve people at all levels in the company [4].

Financial statements are credible information sources by the financial statements users to determine the performance of management and the company's financial position. To produce quality financial reports it is required financial reporting 
quality. It should also be supported by internal control over quality financial reporting [4].

\section{LITERATURE REVIEW}

The financial statement is the financial effects overview of transactions and other events which are classified into several large groups according to their economic characteristics. The financial statements which are the output of accounting, financial reporting is not the final product it is a process that starts from the transactions/events, the selection of accounting policies and then apply the policy. Financial reporting also involves estimates and judgments as well as the disclosures about transactions, events, policies, estimates and judgments that have been made. The quality of financial reporting depends on the quality of each part of the financial reporting process [5]

According to Committee of Sponsoring Organization of The Tread way Commission, internal control is defined as follows:

Internal control is a process, affected by entity's board of directors, management and other personnel, designed to provide reasonable assurance regarding the achievement of objectives in the following categories: Effectiveness and efficiency of operations;Reliability of financial reporting ;Compliance with applicable laws and regulations [6].

From the quotation, we can conclude that therefore it is important for all managers in an organization to understand the importance of implementing and maintaining effective internal control which is the responsibility. COSO definition of internal control makes it clear that the internal control does not only affect the financial statements which are reliable but indicates that the control should be effective for all operations and compliance with applicable laws and regulations.

There are three objectives which are expected by management in designing the effectiveness of internal control, it is associated with:

- the effectiveness and the efficiency of activities;

- the information reliability;

- Compliance with applicable laws and regulations.

The components of internal control consist of the control environment, risk assessment, control activities, information and communication and monitoring [6].

\section{RESEARCH METHODS}

The method which is used in this study is a survey method, because it has the characteristics that are associated with the objectives to be achieved, it is descriptive and verification, and the data is collected from a sample that has been determined, it is obtained by using a specific data collection tools, the questionnaires.

The object of this research are the role of sharia supervisory board, and the quality of financial reporting. The research subject is ZMO which operates in Bandung city. The respondents in this study are director, members of Zakat collection and utilization. The data which is obtained from the ZMO respondents will be averaged, so that the opinion of respondents representing each ZMO. The data source which is required in this research will be obtained through the Field Research by distributing questionnaires and Research Library (Library Research). The data quality which is obtained from the respondents through the questionnaire needs to be tested by doing validity test and reliability test to avoid things that are biased and question the validity of this study.

The testing hypothesis uses moment product correlation and coefficient of determination (R2). The more the value of $\mathrm{R} 2$ is closed to one then the independent variable provides almost all the information which is needed to predict the variation of dependent variable. On the contrary, if the value of $\mathrm{R} 2$ is getting smaller, the ability of independent variable in explaining the dependent variation is very limited.

\section{RESULT AND DISCUSSION}

The relation of internal control implementation with the quality of financial reporting is positive and very strong. The results are consistent with the research of Petrovits et al which conducts the research on the causes and consequences of internal control problem in non-profit organizations that prove the poor reporting for nonprofit organizations is caused by weak internal control, then effects on the organization which is not transparent and is not accountable [7]. Altamuro and Beatty suggests an increase in monitoring and reporting on internal control to improve the quality of financial reporting in banking industry [8]. The importance of internal control over financial reporting in realizing the quality of financial reporting is also presented [9], [10],[11], [12],[13] they found that Good internal control implementation will improve the quality of financial reporting.

\section{CONCLUSION}

Based on the results, it is concluded that the relation of internal control implementation with the quality of financial reporting is positive and very strong. Financial statements are credible information sources by the financial statements users to determine the performance of management and the company's financial position. Therefore implementation of internal control can improve the quality of financial reporting that will ultimately result in increased public confidence in the ZMO.

\section{REFERENCES}

[1] Mediawati, E. (2016). The Quality of Financial Reporting : Sharia Supervisory Board Role in Zakat Management Organization. 1st UPI International Conference on Sociology Education (UPI ICSE 2015). Atlantis Press

[2] Kinney,W. 2001. Accounting Scholarship: What is unique ours. Accounting review, pp 275-284

[3] Kinney,W., et al. 1990. Assertion Based Standars for Integrated Internal Control. Accounting Horizon, 4, pp $1-8$

[4] Deloitte and Touche LLP,et al. 2004. Internal control over financial reporting an investor resources. 
[5] Jonas,Gregory and Jeanot, Blanchet.2000. Asessing Quality of Internal Quality.Accounting Horizon, Sept; 14,3 , 353

[6] Committee of Sponsoring Organization (COSO). 1994. Internal Control Integrated Framework. AICPA Publications.

[7] Petrovits. Christine, Chaterine Shakespeare and Aimee Shih.2010. The Causes and Consequences of Internal Control Problems in Nonprofit Organizations. Social Science research Network: 49

[8] Altamuro,Jenifer, and Anne, Beatty. 2010. How Does Internal Regulation affect financial reporting?. Journal of Accounting and Economics 49 (1-2), 58-74 Committee of Sponsoring

[9] Agami,Abdel.M. 2006. Reporting on Internal Control over financial reporting. The CPA Journal. November 76,11: 32-34
[10] Miichelman, Jeffrey. 2008. Improving Internal Control Over Financial Reporting. The CPA Jornal. April, 78,4., 30 - 34

[11] Ollach,Tom, and Syayamini Weeramantri. 2009. How COSO has improved Internal Control in the United States. Internal Auditing. Nov/Des, 24,6; 3-12

[12] Rittenberg, Larry. 2007. Internal Control No Small Matter. The Internal Auditor.Oct, 63,5: 16-17

[13] Doyle, Jeffrey, Welli Ge, and Sarah McVay. 2007. Determinant weakness of Internal control over financial reporting. Journal of Accounting and economics. Vol.44 : 193-223 